Check for updates

London

Cite this as: $B M J 2020 ; 371: \mathrm{m} 4940$ http://dx.doi.org/10.1136/bmj.m4940 Published: 22 December 2020

\title{
Covid-19: Chaotic decision making and failure to communicate undermined government response, says report
}

Shaun Griffin

Ministers must improve the way they use and communicate advice from scientists or risk repeating mistakes made earlier in the coronavirus pandemic, a think tank has warned.

A report from the Institute for Government outlined a series of errors it said the government made in the past 10 months: from the lack of a coherent strategy when lockdown restrictions were lifted in May to its failure to consult scientists on "epidemiologically illiterate" policies, such as the "Eat Out to Help Out" scheme, and its delay in consulting the Scientific Advisory Group for Emergencies on the return of students to universities. ${ }^{1}$

Many such problems had been seen in the government's handling of past crises, such as the outbreaks of bovine spongiform encephalopathy, foot and mouth disease, and $\mathrm{H}_{1} \mathrm{~N}_{1}$ "swine" flu, said the report. These included the blurring of policy decisions and expert advice, relying on uncertain modelling and "groupthink," and a lack of transparency in explaining how evidence and advice were used.

Tom Sasse, associate director at the institute and an author of the report, said that the pandemic response had so far "too often been undermined by misunderstanding the role of science advice and using it inconsistently." He added, "Looking to scientists to make judgments only politicians can make has contributed to the government delaying the first lockdown.

"Haphazard communication of key public health messages switched between alarm and reassurance while failing to drive home key points such as the risk of gathering indoors." Furthermore, a lack of transparent evidence had undermined confidence in government policies, such as the plan to reopen schools in June, he said.

"Ministers repeatedly insisted they were 'following the science.' But the decision over Christmas bubbles is yet another example of the government delaying decision making and failing to use scientific advice well-or to communicate a consistent message to the public," said Sasse. "There are difficult months of restrictions and vaccine rollout to come in 2021. Ministers must avoid repeating the damaging mistakes of this year."

\section{SAGE role praised}

The report noted that, despite being an ad hoc body, SAGE had responded well under pressure. Its co-chairs, Patrick Vallance and Chris Whitty, adapted the group in response to the crisis when it was not designed to take on such a prolonged role.
SAGE has met more than 70 times to discuss covid, whereas in previous crises it met no more than five times. After the first few weeks the Department of Health and Social Care for England and Public Health England, and their devolved equivalents, would have been expected to take over the ongoing response, but this did not happen. Instead, Number 10 opted to retain greater control and keep SAGE running, even after the high level Cabinet Office group stopped meeting.

Sasses said that although there were "valid criticisms about the range of disciplines represented in [SAGE's] membership... the greater problem has been chaotic decision making from the top of government." This has repeatedly created problems in how SAGE's work is commissioned and how its members understand the way their advice is used.

\section{Recommendations}

The institute called on covid cabinet committees to better integrate scientific, economic, and other advice in making decisions in the coming months and for ministers to explain clearly how trade-offs are made. The government must also make more use of scientist led briefings to explain to the public the reasons for its measures.

The institute also said that the Treasury should publish economic analyses of the costs and effects on wellbeing of implementing, or not implementing, public health restrictions.

In the longer term the government should strengthen science capability across the civil service, develop strong working relations with ministerial scientific advisers, and make more consistent use of groups tasked with finding weaknesses in crisis response plans.

Haddon C, Sasse T, Nice A. Science advice in a crisis. Institute for Government. Dec 2020. https://www.instituteforgovernment.org.uk/publications/science-advice-crisis.

This article is made freely available for use in accordance with BMJ's website terms and conditions for the duration of the covid-19 pandemic or until otherwise determined by BMJ. You may use, download and print the article for any lawful, non-commercial purpose (including text and data mining) provided that all copyright notices and trade marks are retained. 